Impulsive buying, cultural values dimensions, and symbolic meaning of money: A study on college students in Indonesia's capital city and its surrounding

Dameyasani, Aulia Wika

Department of Psychology, Bina Nusantara University, Indonesia (dameyasani@gmail.com) Abraham, Juneman $\triangle$

Department of Psychology, Bina Nusantara University, Indonesia (juneman@binus.edu)

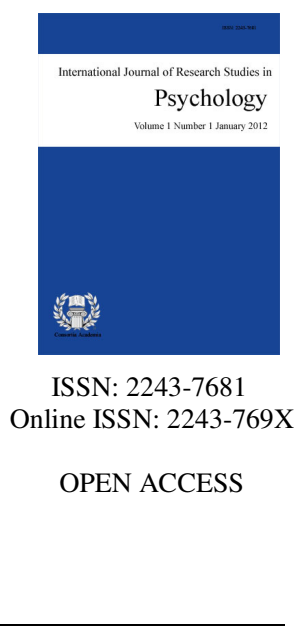

Received: 2 March 2013
Available Online: 10 August 2013

Revised: 2 May 2013

Accepted: 9 August 2013

\title{
Abstract
}

Impulsive buying is an interesting research topic for psychologists and economists for its practical implications in the daily lives of producers, marketers and consumers in the trading world. The topic is also relevant to both micro and macro economy field of studies. There have been abundance explanations for impulsive buying social phenomenon provided, but the cultural factors points of view are rarely studied empirically. This research showed its original contribution to the body of knowledge of buying impulsiveness since it includes the Hofstede's cultural dimensions on individual level in its research model. In addition, the research employed the symbolic meaning of money for predictor variable of impulse buying. There were 200 Indonesian students participated in this research (91 males, 109 females) and they went to seven campuses located in Jakarta and its surrounding areas. The multiple linear regression analysis showed that that power distance belief, collectivism, and symbolic meaning of money all together positively related to impulsive buying. The uncertainty avoidance cultural dimension and impulsive buying are negatively correlated. It has been expected that this research will be much beneficial for all stakeholders. They can manage the perception of culture and symbolic meanings of money in order to lever, improve or decrease impulsive buying according to whatever the stakeholder's goal is. Discussion and suggestions for further similar research are elaborated in the last section of this report.

Keywords: impulse buying; culture; money; symbolic meaning; consumer behavior 


\section{Impulsive buying, cultural values dimensions, and symbolic meaning of money: A study on college students in Indonesia's capital city and its surrounding}

\section{Introduction}

In June 2011, Nielsen issued a research report stating that Indonesian shoppers are becoming more impulsive. Its indications are as follows: (1) From 2003 to 2011, there has been a 10 percent decrease (from 15 percent to 5 percent) among Indonesian shoppers who stated that they planned their purchases and never purchased additional and unplanned goods, (2) From 2003 to 2011, there has been an 11 percent increase (from 10 percent to 21 percent) among shoppers who said that they never planned things they wanted to buy before shopping, (3) From 2003 to 2011, there has been a 26 percent increase (from 13 percent to 39 percent) among shoppers who said they always purchased additional goods even though they used to plan their purchases, (4) From 2003 to 2011, there has been changes in buying patterns, where there has been shifting from 69 percent of shoppers in 2003 saying they might purchase additional goods shifting to 39 percent of shoppers in 2011 saying they always purchased additional goods, also (5) From 2008 to 2011, there has been a 16 percent increase (from 5 percent to 21 percent) among shoppers who used to visit stores that provide attractive offers and coupons promoted through newspapers and flyers (Nielsen, 2011; Industrial Post, 2011). These indications were obtained by Nielsen through direct interview with 1,804 respondents in Jakarta, Bandung, Surabaya, Makasar, and Medan.

According to Verplanken and Sato (2011, p. 198), the most appropriate definition of impulse buying is as stated by Rook, i.e.:

Impulse buying occurs when a consumer experiences a sudden, often powerful and persistent urge to buy something immediately. The impulse to buy is hedonically complex and may stimulate emotional conflict. Also, impulse buying is prone to occur with diminished regard for its consequences (Rook, 1987, p. 191).

There are three characteristics of impulse purchase stated in the above definition, namely (1) unplanned purchases, (2) purchases which are hard to control, and (3) purchases guided by emotional responses. It should be noted that impulse buying is not merely an unplanned purchase. It is possible that an unplanned purchase is not impulsive, such as a habitual purchase, an unexpected purchase that solves a problem or a purchase that does not require planning. On the other hand, planned purchases can be impulsive; for example, searching a gift for someone (Verplanken \& Sato, 2011).

Faced with such reality, as revealed by the above Nielsen report (2011), a literature search in Indonesia showed numerous research describing the impulsive buying behavior (in English terminology: impulsive buying, impulse buying, impulsive purchasing, unplanned buying, buying impulsiveness) has been conducted, especially in undergraduate and master thesis, while it is still very rare in scientific journals. The studies try to explain impulsive purchase with the following variables: product characteristics, reference groups, retail environment and promotion; engagement (involvement) and positive emotions towards products/goods; information exposure (such as television advertisement) and product knowledge; attitudes toward sales promotion; demographic characteristics (gender, age and income), the type of product and store atmosphere; discounts or rebates and consumer behavior characteristics; attraction (message, visual, etc.) and point of purchase; self-concept discrepancy or gap; individualistic and collectivistic cultural orientation, demographic (jobs and income) and store atmosphere; considerations to purchase (utility/function, emotion, intrinsic aspects of the product, consumer identity expression, etc.), product category (food and beverages, clothing, jewelry, electronic, equipment, sports equipment, etc.) and gender; self-monitoring, self-esteem and materialism; emotional awakening and hedonistic considerations (Astuti \& Fillippa, 2008; Djudiyah, 2002; Hapsari, 2005; Harviona, 2010; Herabadi, Verplanken, \& van Knippenberg, 2009; Kasali \& Haryanto, 2008; Peranginangin, 2011; 
Prameswari, 2009; Soeriakartalegawa, 1994; Triaji, 2012; Zakiar, 2010).

Outside of Indonesia, impulse buying research is related to the following variables: self-image, cognitive dissonance/gap, traumatic brain injury, clinical-psychiatric disorders, experience of participating in personal finance education/course, attitudes toward credit cards and history of treating money as a reward in the family, behavior of worshipping idols (idolatrous behavior), personality factors and online social capital (de Kervenoael, Aykac, \& Palmer, 2009; George \& Yaoyuneyong, 2010; Harston, 2002; Hussain et al., 2011; Lai, 2010; Mueller et al., 2010; Niu \& Wang, 2009; Rochat et al., 2011; Youn \& Faber, 2000).

Based on the above research, it is clear that previous research did not give adequate discussion to the dimension of culture as perceived within the level of the individual consumer, except in the theses of Harviona (2010), Kacen and Lee (2002), and Mai et al. (2003) pertaining to individualistic and collectivistic cultural orientation. Premananto (2007), quoting Herabadi (2003) and Kacen and Lee (2002), mentioned cultural factor as a moderator of the relationship between traits and impulsive buying behavior. However, there was no empirical test in his publication. It appears that much of the research has associated impulsive buying with the "4P's of Marketing Mix" (Price, Product, Place, and Promotion), self and personality. Therefore, this current study fills the existing literature gap by including cultural variables as predictors of impulse buying. Another significance of this study as compared to other similar studies (Harviona, 2010; Kacen \& Lee, 2002; Mai et al., 2003 ) is the inclusion of not only collectivism-individualism, but all possible dimensions of Hofstede's cultural values (as will be stated below).

"Culture" in this study, along with its dimensions, follows the explanations of Hofstede (2001) and Hofstede, Hofstede and Minkov (2010, p. 255-258). They defined culture as the collective mental programming of the human mind which distinguishes one group of people from another. This programming influences patterns of thinking which are reflected in the meaning people attached to various aspects of life and which become crystallized in the institutions of a society.

There are five dimensions of cultural values (Hofstede, 2001; Hofstede at al., 2010). First, is the belief about power distance (power distance belief), which is abbreviated as PD. This dimension is based on the fact that all individuals in society are not equal. PD is defined as the degree to which members of a culture expect and accept that power is distributed unequally. The characteristics of a high-PD are: (1) dependent on hierarchy, (2) belief about inequality of rights between holders of power (power holders) and those who do not power (non-power holders), (3) the leader is directive, (4) managers take control and do delegation, (5) centralized power, and (6) team members must obey the leaders.

Second, is uncertainty avoidance (UA). This dimension reflects how people deal with the fact that the future is mysterious and ambiguous. The central question then becomes: Do we have to try to control the future (high UA), or do we tolerate and just let the future happen (low UA)? The ambiguity of the future leads to anxiety, and different cultures handle anxiety in many different ways. UA is defined as the degree to which members of a culture feel threatened by ambiguous or unknown situations, and to what extent they will create a belief in order to avoid the situation (Hofstede, 2001; Hofstede at al., 2010).

Third, is collectivism (CO). This dimension is defined as the degree of interdependence between members of the public. Someone who is collectivist describes his/herself by the term "we/us" and not "me/I". The characteristics of a high CO are: (1) people loyal to the group (in group), (2) there is a preference towards social framework, (3) individuals are expected to conform to the ideals of the group, and (4) loyal to family (Hofstede, 2001; Hofstede at al., 2010).

Fourth, is masculinity (MA). This dimension is concerned with the question of what things motivate someone, whether he/she want to be the best (masculine) or prefers things that are liked (feminine). Characteristic of a high MA is that members of the culture are driven by competition, achievement and success. Success is defined by being the winner or being the best in his/her field. On the other hand, the characteristic of 
low MA is the great value being put on caring for other people and their lives (Hofstede, 2001; Hofstede at al., 2010).

Fifth, is long-term orientation (LT). This dimension is defined as to what degree members of a culture show future-oriented pragmatic perspective as compared to short-term conventional historical perspectives (Hofstede, 2001; Hofstede at al., 2010).

This current study connects impulse buying with cultural dimensions for three reasons. First, it has been shown that the general buying behavior is influenced by culture (e.g. Laroche et al., 2007; Money, Gilly, \& Graham, 1998; Legohérel et al., 2009; Ko et al., 2004; Sheth \& Sethi, 1977). Koichi Shimizu (2003, 2009) included Social and Cultural Circumstances in his "7Cs Compass Model of Marketing". Second, it has been shown that culture contributes to self-control or self-regulation (e.g, Slosar, 2009; Ackerman et al., 2009). Small (2009) even mentions the possibility that self-control is not natural: if so, its trait might be cultural. As shown, impulsivity has antagonistic trait towards self-control and vice versa (Kalenscher, Ohmann, \& Güntürkün, 2006). Impulsivity is the lack or the absence of self-control. In terms of impulse buying, self-control includes thinking about how to spend money, avoiding displays of products or managing emotional passion associated with products (Verplanken \& Sato, 2011). When the culture contributes to self-control, then syllogistically it also contributes to impulsivity. Unfortunately, although there have been studies linking culture with self-control (as opposed to impulsivity) and general buying behavior, there are fewer studies which investigate the relationship between culture and impulse buying. This current study, once again, is aimed at filling the gap.

Other than predictor variables of cultural dimensions, the variable of symbolic meaning of money is added in the research model. As known, in addition to having instrumental meaning (tool of economic transactions), money has symbolic, emotional and moral meaning (Baker \& Hagerdon, 2008; Furnham, Wilson, \& Telford, 2012; Gasiorowska, Zaleskiewicz, \& Wygrab, 2012). The symbolic meaning of money has more to do with social learning rather than cognitive development. An example of the emotional meaning of money is the notion that money represents security, freedom, power, love, success, political identity, etc. This study assumes that the intensive emotional aspect of the symbolic meaning of money stimulates people to obtain it. Shopping or buying something is an appropriate means to achieving the symbols. Thus, the more that people are able to see things being symbolized by money, and want to be treated in accordance with the symbol, the more people feel the urgency to buy things in order to realize the imagined symbols attached to the purchased goods.

As this study is the first to include all possible predictors of Hofstede's cultural values and as an exploratory study in Indonesia, the research hypothesis is that the dimension of cultural values is able to predict impulsive buying, but the direction of the relationship (whether it is positive or negative) is not stated. Meanwhile, with regard to the symbolic meaning of money, this study hypothesizes positive correlation.

The third reason for conducting this study is to further broaden the research synergy between economics and psychology. Susianto (2007) described a number of terms that demonstrate the interdisciplinary synergies, such as behavioral economics, mental accounting and money illusion. He also pointed out the fact that in 2002, Daniel Kahneman; a psychologist, acquired a Nobel Prize in Economics for his services to integrate the findings of psychology, in particular the assessment and decision making under uncertainty, in economics (Susianto, 2007; Susianto, 2009). Impulse buying is an interdisciplinary variable that can be studied by psychology and economics, and this article would carry forward the spirit of synergy between economics and psychology that has been pioneered by the previous researchers.

\section{Methods}

\subsection{Participants and Design}

Participants of this study were 200 students in Jakarta; the capital city of Indonesia, and its surrounding 
Impulsive buying, cultural values dimensions, and symbolic meaning of money

areas (91 men, 109 women; $M_{\text {age }}=20.75$ years old, $S D_{\text {age }}=1.35$ years old). Participants were collected through convenience sampling techniques from seven universities in Jakarta and its surrounding areas, namely Trisakti University, Tarumanagara University, Indonesia Atma Jaya Catholic University, Professor Dr. Moestopo University, London School of Public Relations, University of Indonesia, and Pelita Harapan University. Out of the 200 field participants, there were 50 students who tested the measuring instrument.

The research design is a non-experimental, predictive correlational design. Predictor variables are (1) Belief about power distance (PD), (2) Collectivism (CO), (3) Uncertainty Avoidance (UA), (4) Masculinity (MA), and (5) Symbolic Meaning of Money (SYM). The dependent variable is impulsive buying (IMP). Data were analyzed with multiple linear regressions by using SPSS 20 for Windows.

\subsection{Instrument}

To measure impulsive buying, Impulsive Buying Tendency was used (IBT; Herabadi, 2003; Verplanken \& Herabadi, 2001). This scale consists of two dimensions, namely a cognitive dimension (e.g. absence of planning, accident), and an affective dimension (e.g. feeling of pleasure, joy, buying impulse, difficult not to be attracted to something, lack of control and possibility of post-shopping regret). Each aspect consists of 10 points. This study added a number of items from the scale of Compulsive Buying by Weaver, Moschis, and Davis (2011), and these items were included into the appropriate cognitive or affective dimensions. Although the scale is called Compulsive Buying, these items fit or are at least not contrary to the definition of impulsive buying. DeSarbo and Edwards (1996) explained that although buying compulsivity is driven more by internal motivation and while impulsive buying is triggered more by an external stimulus, compulsive buyers also tend to buy impulsively. In addition, Sun, $\mathrm{Wu}$, and Youn (2004) found a positive correlation between impulsive buying with compulsive buying. They also explained that the impulsive and compulsive buying are on a continuum, in cases where chronic impulsive buying can develop into compulsive buying.

The response options for this scale are "Strongly Disagree" (score of 1), "Disagree" (score of 2), "Somewhat Disagree" (score of 3), "Somewhat Agree" (score of 4), "Agree" (score of 5), and "Strongly Agree" (score of 6).

Instrument tests show that the IBT scale of cognitive dimension has high internal consistency based on its Cronbach's Alpha index $(\alpha=0.80)$ with corrected item-total correlations range from 0.31 to 0.61 , which means it meets criteria of reliability $(\alpha>0.60)$ and validity $\left(r_{i t}>0.25\right)$. Meanwhile, the affective dimension of IBT scale has high internal consistency $(\alpha=0.78$ ) with corrected item-total correlations ranges from 0.34 to 0.51 .

For more details, complete instrument is presented in Table A (see Appendix).

To measure the symbolic meaning of money, the Meaning of Pay (MOP; Hayes, 2005) based on the dimensions of Thierry (2001) was adapted. The scale was adapted and elaborated to be in line with the target participants namely college students, with initial guidance as follows:

Here you are asked to provide a response as to what money means to you. Money here refers to your total income. This includes the money you receive from your parents, interest on bank savings or insurance benefits, benefits received from working at Student Activity Unit, business you do with your friends, freelance work payments or hobbies, salary and other bonuses (if you work), and others. Please indicate for each item to the extent which you agree or disagree with that statement. The correct answer is the answer that best describes you.

The MOP consists of 32 items, divided into four dimensions, namely motivation (motivational properties), relative position, control, and expenditures (spending). In the motivation dimension, money is viewed as a means of achieving goals, satisfaction of needs or motives. For example, money is considered a symbol of status in society, recognition, stability, security, expectancy (expectation), and so on. Thus, the motivational significance of money is a reflection of the outcomes that will be fulfilled by money which act as a motivator for the 
individual. In other words, money is the source of abstract and intangible opportunities.

In the dimension of relative position, money provides a reflection of performance related to certain standards or goals, and is a reflection of self-performance in comparison to others. On a broader scale, the relative position shows the level of public appreciation of a person's work. In the dimension of control, money reflects the extent to which a person has the autonomy to manage his/herself and his/her own behavior, as well as self-regulate and regulate the behavior of others, in accordance with the wishes of the person. Thus, money is a reflection of the amount of power and control of the individual, and the value of contributions to others. In the spending dimension, money reflects satisfaction as a result of the ability to purchase concrete or tangible goods and services.

The response options for this scale are "Strongly Disagree" (score of 1), "Disagree" (score of 2), "Somewhat Disagree" (score of 3), "Somewhat Agree" (score of 4), "Agree" (score of 5), and "Strongly Agree" (score of 6).

Instrument tests showed that the MOP scale has high internal consistency $(\alpha>0.60)$ with corrected item-totals correlations greater than 0.25. Dimension of Motivation has an $\alpha=0.81$ and $r_{i t}$ ranges from 0.43 to 0.73. Dimension of Relative Position has $\alpha=0.84$ and $r_{i t}$ ranges from 0.53 to 0.64. Dimension of Control has $\alpha=$ 0.89 and $r_{i t}$ ranges from 0.61 to 0.77 . Dimension of Spending has $\alpha=0.84$ and corrected item-total correlations ranges from 0.49 to 0.71 .

For more details, a sample instrument is presented in Table B (see Appendix).

To measure the dimension of cultural values, the Scale of Individual Cultural Values was used (CVSCALE; Yoo, Donthu, \& Lenartowicz, 2012). CVSCALE consists of five dimensions of cultural values as expressed by Hofstede, Hofstede, and Minkov (2010), but the measurement was conducted within the individual level.

The response options for this scale are "Strongly Disagree" (score of 1), "Disagree" (score of 2), "Somewhat Disagree" (score of 3), "Somewhat Agree" (score of 4), "Agree" (score of 5), and "Strongly Agree" (score of 6).

Instrument tests showed that the CVSCALE of Power Distance dimension has high internal consistency $(\alpha=$ 0.64 ) with corrected item-total correlations ranges from 0.42 to 0.47 , which means it meets the criteria of reliability $(\alpha>0.60)$ and validity $\left(r_{i t}>0.25\right)$. The Uncertainty Avoidance dimension has high internal consistency $(\alpha=0.67)$ with corrected item-total correlations ranges from 0.36 to 0.56 . The Collectivism dimension has high internal consistency $(\alpha=0.66)$ with corrected item-total correlations ranges from 0.31 to 0.70 .

Dimensions of Masculinity and Long-Term Orientation are unreliable $(\alpha<0.60)$, and hence the two dimensions are not included in the field study.

For more details, a complete instrument is presented in Table C (see Appendix).

\section{Results}

Multiple Linear Regression showed the results of $R^{2}=0.461, F(4,199)=41.687, p<0.01$. This means that the beliefs about Power Distance, Uncertainty Avoidance, and Collectivism, also the Symbolic Meaning of Money are able to predict impulsive buying at 46.1 percent. In the social sciences, the size of this contribution is relatively large. The significance of each predictor variable is presented in Table 1. 
Impulsive buying, cultural values dimensions, and symbolic meaning of money

\section{Table 1}

Results of multiple linear regression analysis to predict impulsive buying $(n=200)$

\begin{tabular}{lllllll}
\hline Predictor Variables & $B$ & $S E B$ & $\beta$ & $t$ & $p$ & $r$ \\
\hline (Constant) & 33.94 & 11.95 & & 2.83 & & 0.01 \\
Power Distance Belief (PD) & 2.15 & 0.55 & 0.21 & 3.89 & 0.00 & 0.27 \\
Uncertainty Avoidance (UA) & -1.43 & 0.54 & -0.15 & -2.63 & 0.09 & -0.21 \\
Collectivism (CO) & 0.92 & 0.46 & 0.11 & 1.98 & 0.04 & 0.12 \\
Symbolic Meaning of Money & 0.35 & 0.04 & 0.56 & 10.09 & 0.00 & 0.64 \\
(SYM) & & & & & \\
\hline
\end{tabular}

Thus, the regression equation results of this study are as follows: IMP $=\beta_{0}+\beta_{1} \mathrm{PD}+\beta_{2} \mathrm{UA}+\beta_{3} \mathrm{CO}+\beta_{4}$ $\mathrm{SYM}+\varepsilon ; \mathrm{IMP}=33.94+0.21 \mathrm{PD}-0.15 \mathrm{UA}+0.11 \mathrm{CO}+0.56 \mathrm{SYM}+\varepsilon$; where $\beta_{0}=$ Constant (Intercept); $\beta_{1}$ to $\beta_{4}=$ regression coefficients of each predictor variable; $\varepsilon=$ residual or error.

It appears that the higher the belief of power distance, the higher the impulsive buying $(\beta=0.21)$. This current study also found that the higher the collectivism, the higher the impulsive buying $(\beta=0.11)$; the higher the uncertainty avoidance, the lower the impulsive buying $(\beta=-0.15)$; and the higher the symbolic meaning of money, the higher the impulsive buying $(\beta=0.56)$. Based on the existing Beta value $(\beta)$, it seems that contribution of the symbolic meaning of money is the biggest among other predictor variables, followed by the belief of power distance.

\section{Discussion}

This current study found that a higher belief in the power distance corresponds to higher levels of impulse buying. These results are not in line with the study finding of Zhang, Winterich, and Mittal (2010) which stated that the higher the belief about power distance, the lower the impulsive buying. They explained that people with high power distance belief are associated with high self-control when faced with temptation or opportunity to buy impulsively. The reason is that high power distance adjacent to behavioral concepts such as control/restraint, compliance (obedience), conformity to authority or power, delayed gratification, and compliance with norms (normative compliance) above personal passion or urgency. According to them, this tendency is strongly believed in Eastern cultures. Social expectations in a high power distance suppress/inhibit impulsivity.

However, there are a number of explanations for the contradictory results. Expression of "Asal Bapak Senang” ("Yes Sir Attitude”, “As Long As The Boss is Happy”, "Keep the Boss Happy”, “As Long As It Pleases the Master") are popular expressions and have a network of semantic meaning in Indonesia. Mochtar Lubis in his Culture Speech in 1997 at Taman Ismail Marzuki, Jakarta, which was then recorded by Obor Indonesia (2001: see also: Semma 2008) mentioned that the mentality of “Asal Bapak Senang” is one of Indonesia's human traits. The nature of this expression is further described by Whitfield as follows:

In Indonesia, however, cultural barriers like Asal Bapak Senang come into play. Because of the importance of status differences, subordinates may feel obliged to report good information about a situation that could actually be bad, from a Western point of view (Whitfield, 2012, p. 1).

Valega adds that the symptoms of such barriers are socialized since childhood:

From childhood, children begin to be conditioned to perform actions based on perception of as long as father is happy. For example, when parents are not at home, children watch TV. When the parents come home, they quickly go study. When asked what they are doing, they reply by saying they are studying. It's initial symptom of "as long as the boss is happy”, right? When a child goes through phase transition into a teenager, s/he begins to be conditioned by cheating during exams ... In addition, bribing teachers are also common (Valega, 2012, p. 1). 
Apparently, psychosocial reality in Indonesia is that belief about high power distance is operationalized with the expression of "as long as the boss is happy", namely everything will be done so that the ruling authority is happy. Feudalistic behavior is the norm or social expectations that apply in this case. Ismail Saleh (2012) stated that "budaya upeti" ("tributary culture") is done for the boss with the ultimate goal of making the boss happy, and that without a tribute, any affairs will be neglected or long-winded.

When it occurs chronically, it is not surprising that belief in a high power distance leads to high impulse buying. This is because in the feudalistic mentality of "as long as the boss is happy", buying and delivering goods seem to be a method to make authorities happy. By making the authorities happy, people feel secure because they realize that their goals and actions depend on others who are more powerful. So in this case impulse buying may serve as a kind of "emotional/psychological investment" for the future.

This study found that the higher the collectivism, the higher the impulsive buying. The results are not in line with the results of research by Kacen and Lee (2002), who found that collectivistic cultures (as found in Asian race, Eastern cultures) tend to suppress impulse buying (negative correlation), while the cultures of individualism (as found in Caucasian race, Western culture) support impulsive traits, such as impulsive purchases. They explained that individualistic cultures put more interest on independence (self), individual needs and desires, as well as hedonistic pleasure, which encourage impulsive purchases. Meanwhile, the collectivistic cultures put more interest on interdependence, emotional control, as well as collective desires and needs, which inhibit impulsive purchasing despite the fact that spending culture (shopping culture) is highly developed in East Asia.

However, there are a number of explanations for the contradictory results. For example, we can listen to the reality of everyday expressions as follows:

If you go out of town, the main thought in addition to vacation, is often, associated in particular about buying things, especially food, from the visited place (Ruslina, 2011, p. 1).

But we as Javanese are accustomed to have culture of bringing gifts from a trip. We can give the souvenir to whom we please, especially if we return from abroad (Dini, 2000, p. 333).

Culture of bringing gift is really rooted in Indonesia. I've never found any countries than Indonesia of which people, when they go abroad, buy many souvenirs so insanely. But then again, I also never find any other countries of which people dare to ask for souvenir from those who go out of town or abroad and consequently if they do not get what they dare to ask, then those might feel guilty, even has impression as if not trying to maintain good relationship. So when travelling, Indonesian people seem to be occupied in buying gifts for whom they know (FemaleDaily, 2011, p. 1).

The "culture of bringing gifts" ("budaya oleh-oleh"), as described above, is an explanation that the more collectivist someone is, the higher his/her impulsive buying. In this culture, the urgency of buying goods originates from implicit consciousness and/or collective unconsciousness that the goods purchased are means of maintaining kinship and togetherness with others, also to show sensitivity and concern for others or group. In buying goods, others or the group are always considered or included. So, goods that are impulsively purchased are intended to be offered or given to someone else. To learn more about the meaning of souvenir itself, either as messenger of meaning, tradable commodities, or commodification, the study by Swanson and Timothy (2012), which was recently published, can be beneficial to read.

Another explanation is given by Jalees (2009) who specifically examined the relationship between collectivism with impulsive buying in Pakistan. Jalees found similar results to the findings of this study, in that collectivism (and not individualism) is the predictor of impulsive buying. Jalees stated that a number of participants who filled in his questionnaires are actually individualistic, however they think that if they associate 
themselves as being individualists, it goes against the norms of society, so participants in his study categorized him/herself as "collectivists", though they are actually individualists who are impulsive in buying behavior. This explanation actually follows Kashima et al.'s (1992) thesis that consistency between attitudes (as filled in the questionnaires) with the actual behavior is weaker in collectivist cultures than in individualist cultures. People with collectivistic cultures are able to maintain inconsistencies between attitudes and behavior. However, Jalees' explanation is still very speculative, and thus requires further empirical testing.

Hausman (2000 as cited in Kongakaradecha \& Khemarangsan, 2012) stated that impulsive buying is correlated with a desire to satisfy social needs. In this case, the purchase of goods is incidental (without plan) to facilitate needs that are considered more important, namely to interact, obtain and collect social approval from significant others or groups. Hausman's explanation is supported by recent empirical findings by Lee and Kacen (2008) that collectivist consumers are more satisfied after performing impulsive buying when they are with significant others (i.e. friends or family) during the time of buying. Collectivist consumers are fragile to interpersonal influence. Luo (2005) added that such effect occurs especially when the nature of the group is cohesive.

Nevertheless, this current research has not differentiated the types of peer groups. Battaglini, Bénabou, and Tirole (2005), in their comprehensive article, Self-Control in Peer Groups, demonstrated that the kinds of groups - whether members of the group are homogeneous or heterogeneous, whether the group has high or low confidence, whether the group have excessive or deficient self-regulation, and whether the group membership is exogenous formed at school or voluntary (deliberately joined)—affect a person's self-control in the group through process of social learning. This is particularly relevant and applicable for research on impulsive buying in its relation to collectivistic culture. Further research is strongly advised to investigate this.

Another explanation why collectivism and impulsive buying correlate positively refers to symptoms of group buying or collective buying which are recently growing in Indonesia. The group buying system is described as follows:

In simple explanation, group buying is a collective buying system. As we know in general, if we buy something in large quantities then we can get special price. Suppose you want to buy an Asus laptop A42F series. You can gather people who also want to buy this laptop with this series so you can get special price from the seller. That is group buying system (Garry, 2011, p. 1).

Another description regarding group buying:

Online group buying had been facilitated by the Internet and the easy, fast coalition group process brought by social networks (Xiong \& Hu, 2010; as cited in Erdoğmuş \& Çiçek, 2011, p. 309)

At the time this article was written, there have been 28 websites which offer group buying in Indonesia, and can be accessed at http://www.dskon.com/website-group-buying/. One of the groups that has a high preference of buying through online group buying is the college student group (Erdoğmuş \& Çiçek, 2011), in line with participants of this study, which is characterized by openness to change and love to try new products and new services offered by the online group buying.

This collective buying can increase impulsive buying due to interesting discounts and time limited offer (expiration), such as 24 hours, thus creating a sense of urgency to buy and supported by the cultural influences of collectivism or "flock mentality" (Hong Kong Trade Development Council, 2012; Kim, Lam, \& Tsai, 2012). Oh and Jha (2011) added that collectivism affects bargaining dynamics. In group buying, customers join via internet "to leverage the collective bargaining power and negotiate higher discount from retailers".

Based on the above explanation, direct correlation between collectivism with impulse buying can now be better understood. 
A subsequent finding of this study is that the higher the uncertainty avoidance, the lower the impulsive buying. This result is in line with the proposition of Leo, Bennett, and Cierpicki (2005) which states that there is negative correlation between the two variables. They explained that people with high uncertainty avoidance cultures tend to need more information before they act, and resist innovation and change, and therefore less impulsive. A similar explanation was given by de Mooij (2010). He stated that high impulsive buying is more related to thrill, variety, and sensation seeking, also stimulation, and all of these matters are related to the low degree of uncertainty avoidance, not high.

Thus, it is understandable why uncertainty avoidance correlates with impulsive buying in the opposite direction. However, further research is recommended to examine the predictive relationship between the two variables through mechanism of social comparison. Butzer and Kuiper (2006) found that intolerance of uncertainty (or in other words: high uncertainty avoidance) correlated positively with frequency of doing social comparison. It means that the more people avoid uncertainty, the more people compare themselves with others, either comparing themselves with people who are better, more successful, richer, more fortunate, and so on (upward social comparison, $r=0.23, p<0.05$ ) or with people who are worse, failure, poorer, less fortunate, and so on (downward social comparison, $r=0.29, p<0.05$ ). It is interesting and important for the next researchers to examine specifically how upward and downward social comparisons, as a consequence of uncertainty avoidance, can influence consumer impulsive buying.

This current study also found that the higher the symbolic meaning of money, the higher the impulsive buying. Previously there have not been any studies linking these two variables.

As has been stated earlier, money has symbolic and affective meaning. In this case money is not just a medium of exchange or substitution of goods, but also has intangible meaning. Because of this latter meaning, it can be said that something that people want to buy is not the thing per se but the meaning behind the thing that they buy (what is "signalled" by the thing). What is satisfied is not only physiological-homeostatistical needs, but also psychological needs, such as the needs for social or group recognition, social status, future security, need for self-image consistency, need for being different from the other members of the group, and others. Witt (2012) termed it as "symbolic consumption", and the received symbols are usually results of social convention or consensus, or social construction.

A further question is: how is the mechanism that allows the symbolic meaning of money to be positively correlated with impulsive buying? Based on the study of Witt (2012) and Starr (2007), this current study explains that positive correlation between the two is based on the involvement of third intervening variable namely process of social learning, i.e. process of learning, supporting and interacting with social and cultural atmosphere in which material acquisition and gratification is prioritized. Its objects of learning are representations of consumption in culture of contemporary capitalism, and this can be rooted in social-political-economic structure in community (Starr, 2007). The more one learns to put intensive meaning regarding the social construction of their environment (including mass media) on things that can be symbolized with money, the more he/she will competitively pursue acquisitions of the symbol. As a consequence, people become more sensitive to signs or symbols attached to items that are considered natural, legitimate, and desirable. Thus, the body and feelings of well-being have undergone commodification, and are no longer authentic, as they have been subordinated and dominated by values, practices, and rhythms of symbolic consumption, which actually are created and driven by capitalistic industry and environment (Carlisle, Hanlon, \& Hannah, 2008). When this happens, impulsive buying is established and preserved. Therefore, in practice, it is suggested to develop self-awareness as an agency that is able to resist glossy illusion of the "good life" as represented by modern capitalism. In order not to get caught up in impulsive buying, the community should establish and develop their own social capitals and cultural assets which are constantly articulated either through art, music, theater, dance, and so on (process of conscientization).

This study is the first empirical study that investigates impulsive buying behavior by utilizing dimensions of culture and symbolic meanings of money, especially in Indonesia. This study concludes that the cultural 
Impulsive buying, cultural values dimensions, and symbolic meaning of money

dimensions, in particular beliefs about power distance, uncertainty avoidance, and collectivism, along with symbolic meaning of money are significant predictors towards impulsive buying.

This study contributes as a response to Maheswaran and Shavitt's (2000) concern regarding the undeveloped systematic research linking cultural differences in consumer behavior. This study is also an attempt to answer Susianto's concern $(2007,2009)$ about the need to have more interdisciplinary research between psychology and economics.

The results of this study have not included predictors of dimensions of masculinity and long-term orientation. We cannot say that the two dimensions are definitely not related at all with impulsive buying because the instrument pilot phase showed that the instrument intended to measure the two dimensions does not have adequate reliability and validity index. Thus, conclusions related to the two dimensions cannot be reached. Therefore, further research is recommended to re-construct instruments with respect to the two dimensions, and relate them to impulsive buying.

This study has not distinguished types of impulsive buying, namely pure impulse, suggestion impulse, reminder impulse and planned impulse; also has not distinguished four impulsive shopping styles, namely accelerator impulse, compensatory impulse, break-through impulse, and blind impulse (see: Kumar, 2009, p. 479). Further research can elaborate these types and styles as dependent variables.

As an initial study that focuses on cultural comprehension, the theoretical status of this study seems quite promising and may be developed and strengthened in the future.

\section{References:}

Ackerman, J. M., Goldstein, N. J., Shapiro, J. R., \& Bargh, J. A. (2009). You wear me out: The vicarious depletion of self-control. Psychological Science, 20(3), 326-332. http://dx.doi.org/10.1111/j.1467-9280.2009.02290.x

Astuti, R. D., \& Fillippa, M. (2008). Perbedaan pembelian secara impulsif berdasarkan tingkat kecenderungan, kategori produk, dan pertimbangan pembelian [In Indonesian]. Jurnal Ichsan Gorontalo, 3(1), 1441-1456.

Baker, P. M., \& Hagerdon, R. B. (2008). Attitudes to money in a random sample of adults: Factor analysis of the MAS and MBBS Scales, and correlations with demographic variables. Journal of Socio-Economics, 37 , 1803-1814. http://dx.doi.org/10.1016/j.socec.2008.02.004

Battaglini, M., Bénabou, R., Tirole, J. (2005). Self-control in peer groups. Journal of Economic Theory, 123, 105-134. http://dx.doi.org/10.1016/j.jet.2005.04.001

Butzer, B., \& Kuiper, N. A. (2006). Relationships between the frequency of social comparisons and self-concept clarity, intolerance of uncertainty, anxiety, and depression. Personality and Individual Differences, 41 , 167-176. http://dx.doi.org/10.1016/j.paid.2005.12.017

Carlisle, S., Hanlon, P., \& Hannah, M. (2008). Status, taste and distinction in consumer culture: Acknowledging the symbolic dimensions of inequality. Public Health, 122, 631-637. http://dx.doi.org/10.1016/j.puhe.2007.09.011

de Kervenoael, R., Aykac, D. S. O., \& Palmer, M. (2009). Online social capital: Understanding e-impulse buying in practice. Journal of Retailing and Consumer Services, 16, 320-328. http://dx.doi.org/10.1016/j.jretconser.2009.02.007

de Mooij, M. (2010). Consumer behavior and culture: Consequences for global marketing and advertising (2nd ed.). Thousand Oaks, CA: Sage Publications.

DeSarbo, W., \& Edwards, E. (1996). Typologies of compulsive buying behavior: A constrained clusterwise regression approach. Journal of Consumer Psychology, 5, 231-262.

Dini, Nh. (2000). Jepun negerinya Hiroko [In Indonesian]. Jakarta: Gramedia Pustaka Utama.

Djudiyah. (2002). Hubungan antara pemantauan diri, harga diri, materialisme dan uang saku dengan 
pembelian impulsif pada remaja [In Indonesian]. Unpublished master's thesis, Program Studi Magister Psikologi, Universitas Gadjah Mada, Yogyakarta.

Erdoğmuş, I., \& Çiçek, M. (2011). Online group buying: What is there for the consumers? Procedia Social and Behavioral Sciences, 24, 308-316. http://dx.doi.org/10.1016/j.sbspro.2011.09.138

FemaleDaily. (2011). Benarkah orang Indonesia gila belanja? [In Indonesian] FemaleDaily.com. Retrieved February 15, 2013, from http://femaledaily.com/showthread.php?p=2045977

Furnham, A., Wilson, E., \& Telford, K. (2012). The meaning of money: The validation of a Short Money-Types measure. Personality and Individual Differences, 52, 707-711. http://dx.doi.org/10.1016/j.paid.2011.12.020

Garry. (2011). Website group buying Indonesia [In Indonesian]. Retrieved February 15, 2013, from http://www.computesta.com/blog/2011/05/website-group-buying-indonesia/\#.UC2dUaC5Le4

Gasiorowska, A., Zaleskiewicz, T., \& Wygrab, S. (2012). Would you do something for me? The effects of money activation on social preferences and social behavior in young children. Journal of Economic Psychology, 33, 603-608. http://dx.doi.org/10.1016/j.joep.2011.11.007

George, B. P., \& Yaoyuneyong, G. (2010). Impulse buying and cognitive dissonance: A study conducted among the spring break student shoppers. Young Consumers, 11(4), 291-306. http://dx.doi.org/10.1108/17473611011093925

Hapsari, S. N. (2005). Pengaruh dampak promosi penjualan (potongan harga) dan karakteristik perilaku konsumen terhadap perilaku pembelian spontan (impulse buying): Studi pada konsumen HERO supermarket [In Indonesian]. Unpublished bachelor thesis, Program Studi Ilmu Komunikasi Massa, Fakultas Ilmu Sosial dan Ilmu Politik, Universitas Indonesia.

Hartston, H. J., \& Koran, L. M. (2002). Impulsive behavior in a consumer culture. International Journal of Psychiatry in Clinical Practice, 6(2), 65-68. http://dx.doi.org/10.1080/136515002753724045

Harviona, T. V. (2010). Perilaku pembelian impulsif produk pakaian masyarakat urban di kota Jakarta dan Bandung [In Indonesian]. Unpublished master's thesis, Program Studi Magister Manajemen, Fakultas Ekonomi, Universitas Indonesia.

Hayes, S. C. (2005). The relationship between the symbolic meaning of money and referent choice under situations of inequity. Unpublished doctoral dissertation, Faculty of the Graduate School, University of Maryland, Baltimore, USA.

Herabadi, A. G. (2003). Buying impulses: A study on impulsive consumption. Unpublished doctoral dissertation, University of Nijmegen. Retrieved February 15, 2013, from http://repository.ubn.ru.nl/bitstream/2066/19379/1/19379\%20_buyiim.pdf

Herabadi, A. G., Verplanken, B., \& van Knippenberg, A. (2009). Consumption experience of impulse buying in indonesia: Emotional arousal and hedonistic considerations. Asian Journal of Social Psychology, 12(1), 20-31. http://dx.doi.org/10.1111/j.1467-839X.2008.01266.x

Hofstede, G. (2001). Culture's consequences: Comparing values, behaviors, institutions, and organizations across nations (2nd ed.). Thousand Oaks, CA: Sage Publications.

Hofstede, G., Hofstede, G. J., \& Minkov, M. (2010). Cultures and organizations: Software of the mind (Revised and Expanded 3rd ed.). London: McGraw-Hill.

Hong Kong Trade Development Council. (2012). Development of online shopping platforms and group buying websites in China. Retrieved February 15, 2013, from http://www.hktdc.com/info/mi/a/ef/en/1X07XET1/1/Economic-Forum/Development-Of-Online-Shoppi ng-Platforms-And-Group-Buying-Websites-In-China.htm

Hussain, M., Jan, F. A., Iqbal, K., Manzoor, S. R., Rahman, S., \& Imran. (2011). Do people consider self-image in impulse buying behavior in Peshawar, Pakistan? Interdisciplinary Journal of Contemporary Research in Business, 3(8), 674-687.

IndustrialPost. (2011). Pebelanja Indonesia makin impulsif [In Indonesian]. Industrial Post, 2(7). Retrieved February 15, 2013, from http://theindustrialpost.com/wp-content/uploads/2011/11/IP_Edisi8.pdf

Jalees, T. (2009). An empirical analysis of impulsive buying behavior in Pakistan. International Review of Business Research Papers, 5(6), 298-308. 
Impulsive buying, cultural values dimensions, and symbolic meaning of money

Juwita, C. (2008). Pengaruh sikap konsumen ritel pada promosi penjualan terhadap perilaku pembelian impulsif [In Indonesian]. Unpublished bachelor thesis, Program S1 Sosial Bidang Ilmu Administrasi, Fakultas Ilmu Sosial dan Ilmu Politik, Universitas Indonesia.

Kacen, J. J., \& Lee, J. A. (2002). The influence of culture on consumer impulsive buying behavior. Journal of Consumer Psychology, 12(2), 163-176. http://dx.doi.org/10.1207/S15327663JCP1202_08

Kalenscher, T., Ohmann, T., \& Güntürkün, O. (2006). The neuroscience of impulsive and self-controlled decisions. International Journal of Psychophysiology, 62, 203-211. http://dx.doi.org/10.1016/j.ijpsycho.2006.05.010

Kasali, R., \& Haryanto, J. O. (2008). Role of product characteristics, reference group, retail environment, and promotion in creating influence power, impulsive buying, and autobiographical memory. Journal of Population, 14(1), 1-23.

Kashima, Y., Siegal, M., Tanaka, K., \& Kashima, E. S. (1992). Do people believe behaviours are consistent with attitudes? Towards a cultural psychology of attribution processes. British Journal of Social Psychology, 31, 111-124. http://dx.doi.org/10.1111/j.2044-8309.1992.tb00959.x

Kim, T H., Lam, K., \& Tsai, C. (2012). The group on effect in China. Retrieved February 15, 2013, from http://knowledge.wharton.upenn.edu/articlepdf/2899.pdf

Ko, H., Jung, J., Kim, J., \& Shim, S. W. (2004). Cross-cultural differences in perceived risk of online shopping. Journal of Interactive Advertising, 4(2), 20-29. http://dx.doi.org/10.1080/15252019.2004.10722084

Kongakaradecha, S., \& Khemarangsan, A. (2012). A pilot study of impulse buying behavior in Bangkok, Thailand. Proceedings of the 2nd National and International Graduate Study Conference. Retrieved February 15, 2013, from http://www2.graduate.su.ac.th/proceedings/NGSC_IGSC/IGSC/data/256.pdf

Kumar, S. R. (2009). Consumer behaviour and branding: Concepts, readings and cases, the Indian context. India: Pearson Education.

Lai, C. W. (2010). How financial attitudes and practices influence the impulsive buying behavior of college and university students. Social Behavior and Personality, 38(3), 373-380. http://dx.doi.org/10.2224/sbp.2010.38.3.373

Laroche, M., Yang, Z., Kim, C., \& Richard, M. O. (2007). How culture matters in children's purchase influence: A multi-level investigation. Journal of the Academy of Marketing Science, 35(1), 113-126. http://dx.doi.org/10.1007/s11747-007-0016-6

Lee, J. A., \& Kacen, J. J. (2008). Cultural influences on consumer satisfaction with impulse and planned purchase decisions. Journal of Business Research, 61, 265-272. http://dx.doi.org/10.1016/j.jbusres.2007.06.006

Legohérel, P. Daucé, B., Hsu, C. H. C., \& Ashok, R. (2009). Culture, time orientation, and exploratory buying behavior. Journal of International Consumer Marketing, 21(2), 93-107. http://dx.doi.org/10.1080/08961530802153029

Leo, C., Bennett, R., \& Cierpicki, S. (2005). A comparison of Australian and Singaporean consumer decision making styles. Journal of Customer Behavior, 4(1), 17-45. http://dx.doi.org/10.1362/1475392053750324

Lubis, M. (2001). Manusia Indonesia [In Indonesian]. Jakarta: Yayasan Obor Indonesia.

Luo, X. (2005). How does shopping with others influence impulsive purchasing? Journal of Consumer Psychology, 15(4), 288-294. http://dx.doi.org/10.1207/s15327663jcp1504_3

Maheswaran, D., \& Shavitt, S. (2000). Issues and new directions in global consumer psychology. Journal of Consumer Psychology, 9(2), 59-66. http://dx.doi.org/10.1207/S15327663JCP0902_1

Mai, N. T. T., Jung, K., Lantz, G., \& Loeb, S. G. (2003). An exploratory investigation into impulse buying behavior in a transitional economy: A study of urban consumers in Vietnam. Journal of International Marketing, 11(2), 13-35. http://dx.doi.org/10.1509/jimk.11.2.13.20162

Money, R. B., Gilly, M. C., \& Graham, J. L. (1998). Explorations of national culture and word-of-mouth referral behavior in the purchase of industrial services in the United States and Japan. Journal of Marketing, 62, 76-87. http://dx.doi.org/10.2307/1252288

Mueller, A., Claes, L., Mitchell, J. E., Wonderlich, S. A., Crosby, R. D., \& de Zwaan, M. (2010). Personality 
prototypes in individuals with compulsive buying based on The Big Five Model. Behaviour Research and Therapy, 48(9), 930-935. http://dx.doi.org/10.1016/j.brat.2010.05.020

Nielsen. (2011). One in four main shoppers is male: Nielsen. Retrieved February 15, 2013, from http://www.acnielsen.co.id/news/Release210611.shtml

Niu, H. J., \& Wang, Y. D. (2009). Work experience effect on idolatry and the impulsive buying tendencies of adolescents. Adolescence, 44(173), 233-243.

Oh, H., \& Jha, I. (2011). Cultural values and changing dynamics impact Chinese consumer behavior: Rapid socioeconomic change combines with traditional values to create a complex spending picture. Retail Property Insights, 18(3), 45-50.

Peranginangin, K. Y. (2011). Perilaku pembelian impulsif pada hypermarket Carrefour di kota Jakarta [In Indonesian]. Unpublished master's thesis, Program Studi Magister Manajemen, Fakultas Ekonomi, Universitas Indonesia.

Prameswari, B. (2009). Hubungan antara consumer information exposure, product knowledge, dan impulse purchasing behavior terhadap minuman Ready to Drink (Rtd) di Indonesia [In Indonesian]. Unpublished master's thesis, Program Studi Magister Manajemen, Fakultas Ekonomi, Universitas Indonesia.

Premananto, G. C. (2007). Proses pengambilan keputusan pembelian impuls dengan pendekatan psikologi lingkungan dan rantai kausalitas [In Indonesian]. Antisipasi, 10(1), 172-184.

Rochat, L., Beni, C., Billieux, J., Annoni, J. M., \& van der Linden, M. (2011). How impulsivity relates to compulsive buying and the burden perceived by caregivers after moderate-to-severe traumatic brain injury. Psychopathology, 44(3), 158-164. http://dx.doi.org/10.1159/000322454

Rook, D. W. (1987). The buying impulse. Journal of Consumer Research, 14, 189-199. http://dx.doi.org/10.1086/209105

Rucker, D. D., Galinsky, A. D., \& Dubois, D. (2012). Power and consumer behavior: How power shapes who and what consumers value. Journal of Consumer Psychology, 22, 352-368. http://dx.doi.org/10.1016/j.jcps.2011.06.001

Ruslina, S. (2011). Pesona JNE 'lahir' dari budaya oleh-oleh Indonesia” [In Indonesian]. SWA. February 15, 2013, from http://swa.co.id/listed-articles/pesona-jne-lahir-dari-budaya-oleh-oleh-indonesia

Saleh, I. (2012). Suap, upeti, parcel [In Indonesian]. Pelita. Retrieved February 15, 2013, from http://www.pelita.or.id/baca.php?id=38125

Semma, M. (2008). Negara dan korupsi: pemikiran Mochtar Lubis atas negara, manusia Indonesia, dan perilaku politik [In Indonesian]. Jakarta: Yayasan Obor Indonesia.

Sheth, J. N., \& Sethi, S. P. (1977). A theory of cross-cultural buyer behavior. In Woodside, A., Sheth, J. N., \& Bennett, P. (Eds.), Consumer and industrial buying behavior (pp. 369-386). Elsevier. Retrieved February 15, 2013, from http://www.jagsheth.net/docs/A\%20Theory\%20of\%20Cross\%20Cultural\%20Buyer\%20Behavior.pdf

Shimizu, K. (2003). Symbiotic marketing strategy (4th ed.). Souseisha Book Company.

Shimizu, K. (2009). Advertising theory and strategies (16th ed.). Souseisha Book Company.

Slosar, J. R. (2009). The culture of excess: How America lost self-control and why we need to redefine success. US: Praeger.

Small, M. F. (2009). Losing it: Why self-control is not natural. Living Science. Retrieved February 15, 2013, from http://www.livescience.com/3483-losing-control-natural.html

Soeriakartalegawa, W. A. G. (1994). Hubungan antara diskrepansi konsep diri dengan pembelian impulsif: Kajian penelitian deskriptif pada remaja di Jakarta [In Indonesian]. Unpublished bachelor thesis, Program Studi S1 Psikologi, Fakultas Psikologi, Universitas Indonesia.

Starr, M. A. (2007). Saving, spending, and self-control: Cognition versus consumer culture. Review of Radical Political Economics, 39(2), 214-229. http://dx.doi.org/10.1177/0486613407302484

Sun, T., Wu, G., \& Youn, S. (2004). Psychological antecedents of impulsive and compulsive buying: A hierarchical perspective. In A. Cheema \& J. Srivastava (Eds.), The proceedings of the society for consumer psychology 2004 winter conference (pp. 168-174). San Francisco, CA: Society of Consumer 
Psychology.

Susianto, H. (2007). Psikologi, ekonomi, dan Indonesia [In Indonesian]. Jurnal Psikologi Sosial, 13(1), 83-94.

Susianto, H. (2009). Nobel ekonomi untuk psikolog: Pengantar pemikiran psikologi-ekonomi Daniel Kahneman [In Indonesian]. Retrieved February 15, 2013, from http://www.clr.ui.ac.id/2009/12/07/studium-generale-\%E2\%80\%93-nobel-ekonomi-untuk-psikolog-pen gantar-psikologi-ekonomi-daniel-kahn/

Swanson, K. K., \& Timothy, D. J. (2012). Souvenirs: Icons of meaning, commercialization and commoditization. Tourism Management, 33, 489-499. http://dx.doi.org/10.1016/j.tourman.2011.10.007

Thierry, H. (2001). The reflection theory on compensation. In Erez, M., Kleinbeck, U., \& Thierry, H. (Eds.), Work motivation in the context of a globalizing economy. Mahwah, New Jersey: Lawrence Erlbaum Associates.

Triaji, D. (2012). Pengaruh daya tarik point of purchase terhadap keputusan pembelian impuls produk minuman berkarbonasi: Studi pada pengunjung Carrefour MT Haryono [In Indonesian]. Unpublished bachelor thesis, Program Studi Ilmu Administrasi Niaga, Fakultas Ilmu Sosial dan Ilmu Politik, Universitas Indonesia.

Valega, E. (2012). Pendidikan korupsi ada di sekitar kita [In Indonesian]. Kompasiana. Retrieved February 15, 2013, from http://edukasi.kompasiana.com/2012/02/28/pendidikan-korupsi-ada-di-sekitar-kita/

Verplanken, B., \& Herabadi, A. (2001). Individual differences in impulse buying tendency: Feeling and no thinking. European Journal of Personality, 15, S71-S83. http://dx.doi.org/10.1002/per.423

Verplanken, B., \& Sato, A. (2011). The psychology of impulse buying: An integrative self-regulation approach. Journal of Consumer Policy, 34, 197-210. http://dx.doi.org/10.1007/s10603-011-9158-5

Weaver, S. T., Moschis, G. P., \& Davis, T. (2011). Antecedents of materialism and compulsive buying: A life course study in Australia. Australian Marketing Journal, 19, 247-256. http://dx.doi.org/10.1016/j.ausmj.2011.04.007

Whitfield, G. B. (2012). Business across cultures: Conflict resolution strategies in Indonesia. Expat.orid. Retrieved February 15, 2013, from http://www.expat.or.id/business/conflictresolution.html

Witt, U. (2010). Symbolic consumption and the social construction of product characteristics. Structural Change and Economic Dynamics, 21, 17-25. http://dx.doi.org/10.1016/j.strueco.2009.11.008

Yoo, B., Donthu, N., \& Lenartowicz, T. (2012). Measuring Hofstede's five dimensions of cultural values at the individual level: Development and validation of CVSCALE. Journal of International Consumer Marketing, 23(3-4), 193-210.

Youn, S., \& Faber, R. J. (2000). Impulse buying: Its relation to personality traits and cues. In Houch, S. J., \& Meyer, R. J. (Eds.), Advances in Consumer Research, 27, 179-185. Provo, UT: Association for Consumer Research.

Zakiar, E. (2010). Faktor-faktor pendorong konsumen melakukan impulsive buying pada toko-toko ritel fashion di Jakarta [In Indonesian]. Unpublished master's thesis, Program Studi Magister Manajemen, Fakultas Ekonomi, Universitas Indonesia.

Zhang, Y., Winterich, K., \& Mittal, V. (2010). Power-distance belief and impulsive buying. Journal of Marketing Research, 47(5), 945-954. http://dx.doi.org/10.1509/jmkr.47.5.945 


\section{Appendix}

\section{Table A}

Impulsive buying tendency scale

\begin{tabular}{|c|c|}
\hline Dimension & Items \\
\hline Cognitive & $\begin{array}{l}\text { - Saya biasanya berpikir secara hati-hati sebelum membeli sesuatu (I usually think } \\
\text { carefully before I buy something). } \\
\text { - Saya biasanya hanya membeli barang-barang yang saya niatkan untuk saya beli (I } \\
\text { usually only buy things that I intended to buy). } \\
\text { - Apabila saya membeli sesuatu, biasanya saya melakukannya dengan spontan (If I buy }\end{array}$ \\
\hline
\end{tabular}
something, I usually do that spontaneously).

- Untuk sebagian besar pembelian, saya rencanakan terlebih dahulu (Most of my purchases are planned in advance). ${ }^{\text {a }}$

- Saya hanya membeli sesuatu yang benar-benar saya butuhkan (I only buy things that I really need). ${ }^{\text {a c }}$

- Ringan tangan membeli barang tanpa alasan bukanlah gaya hidup saya (It is not my style to just buy things). ${ }^{\text {a }}$

- Saya suka membandingkan antar merek atau brand yang berbeda sebelum saya membeli suatu barang (I like to compare different brands before I buy one). ${ }^{\text {a }}$

- Sebelum saya membeli sesuatu, saya selalu berhati-hati mempertimbangkan apakah saya membutuhkannya (Before I buy something I always consider whether I need it). ${ }^{\text {a }}$

- Saya biasa langsung membeli barang di tempat yang saya kunjungi pada saat itu juga (I am used to buying things "on the spot").

- Saya sering membeli barang-barang tanpa berpikir (I often buy things without thinking).

- Saya seringkali membeli barang-barang yang tidak saya perlukan meskipun saya tahu bahwa uang saya tinggal sedikit (I have often bought things that I do not need even when I knew I had very little money left). ${ }^{\mathrm{b}}$

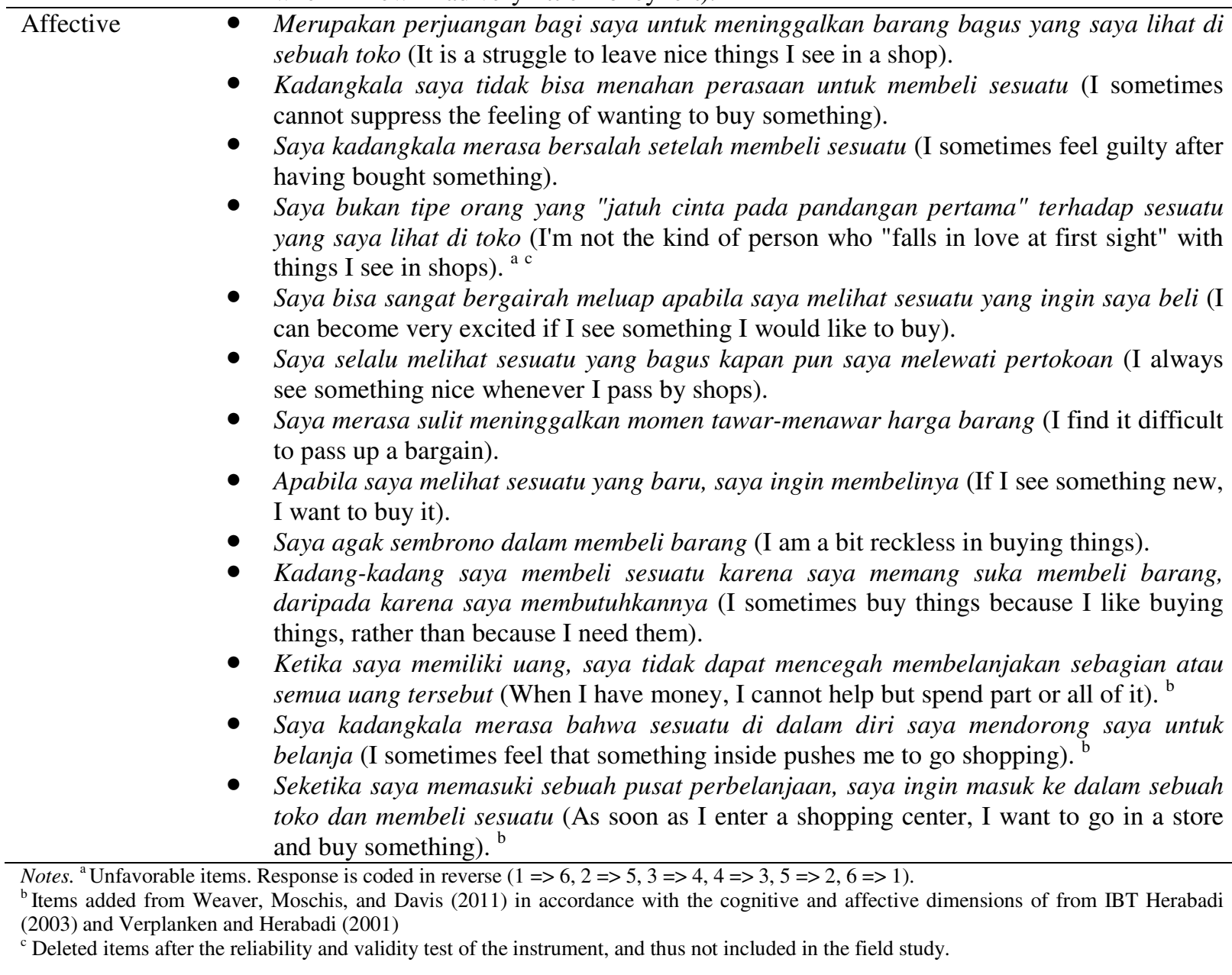




\section{Table B}

Symbolic meaning of money scale

\begin{tabular}{|c|c|}
\hline Dimension & Sample Items \\
\hline Motivation & $\begin{array}{l}\text { - Uang seharusnya memungkinkan saya meningkatkan pertumbuhan pribadi saya (My } \\
\text { pay should enable me to enhance personal growth). } \\
\text { - Uang seharusnya memungkinkan saya membangun hubungan/relasi di luar kuliah } \\
\text { atau pekerjaan (My pay should enable me to establish contacts off the job). } \\
\text { - Uang seharusnya memungkinkan saya untuk dikenal dalam masyarakat (My pay } \\
\text { - Uhould enable me to be recognized in society). } \\
\text { - Should enable me to achieve a stable way of life). }{ }^{\text {a }} \\
\text { - Uang seharusnya memungkinkan saya memperlihatkan keberhasilan saya (My pay } \\
\text { - Uhould enable me to show off my success). } \\
\text { - Shong seharusnya memungkinkan saya untuk dikagumi atas kesuksesan saya (My pay } \\
\text { should me to be admired for my success). }\end{array}$ \\
\hline Relative Position & $\begin{array}{l}\text { - Melalui uang saya memperoleh pengetahuan tentang seberapa baikkah saya } \\
\text { memenuhi hal-hal yang diharapkan dari saya (Through my pay I learn how well I } \\
\text { meet job expectations). } \\
\text { Melalui uang saya belajar tentang prioritas-prioritas dalam kinerja saya [kinerja } \\
\text { dalam Unit Kegiatan Mahasiswa, kinerja akademik, bisnis, dll] (Through my pay I } \\
\text { learn the priorities in my work). } \\
\text { Melalui uang saya memperoleh pengetahuan tentang seefisien apakah kinerja saya } \\
\text { (Through my pay I learn the extent to which I perform my job efficiently). } \\
\text { - Melalui uang saya memperoleh pengetahuan tentang sebaik apakah kinerja saya } \\
\text { dibandingkan dengan teman-teman atau rekan-rekan saya. [kinerja dalam } \\
\text { belajar/kuliah, bekerja/bisnis, UKM, dll] (Through my pay I learn how well I perform } \\
\text { in comparison with my colleagues) } \\
\text { Melalui uang saya disadarkan akan sebaik apakah saya mengerjakan dan } \\
\text { menyelesaikan tugas-tugas atau proyek-proyek kerja yang sulit (Through my pay I } \\
\text { learn how well I took on and completed hard projects at work). }\end{array}$ \\
\hline Control & $\begin{array}{l}\text { - Melalui uang saya memperoleh pengetahuan tentang sebesar apakah kebebasan yang } \\
\text { saya miliki untuk melakukan hal-hal yang saya inginkan (Through my pay I learn how } \\
\text { much freedom I have to do things my own way). } \\
\text { - Melalui uang saya belajar tentang seberapa bertanggungjawabkah saya atas } \\
\text { pekerjaan dari orang lain (Through my pay I learn how responsible I am for the work } \\
\text { of others). } \\
\text { Melalui uang saya memperoleh pengetahuan tentang seberpengaruh apakah opini } \\
\text { - } \text { - Melalui uang saya belajar tentang sebesar apakah pengaruh yang saya miliki atas } \\
\text { aktivitas-aktivitas yang ada dalam departemen / divisi saya (Through my pay I learn } \\
\text { how much influence I have upon the activities of my department). }\end{array}$ \\
\hline Spending & $\begin{array}{l}\text { - Uang seharusnya memungkinkan saya untuk pergi liburan sesuai kehendak saya (My } \\
\text { pay should enable me to go on vacation as I want). } \\
\text { - Uang seharusnya memungkinkan saya membeli barang-barang dan layanan yang } \\
\text { saya inginkan (My pay should enable me to purchase the goods and services I desire). } \\
\text { - Uang seharusnya memungkinkan saya untuk tinggal di manapun saya mau (My pay } \\
\text { should enable me to live where ever I want). }\end{array}$ \\
\hline
\end{tabular}

Note ${ }^{\text {a }}$ Deleted items after reliability and validity test of the instrument, and thus not included in the field study. 
Dameyasani, A. W., \& Abraham, J.

Table C

Scale of individual cultural values

\begin{tabular}{|c|c|}
\hline Dimension & Sample Items \\
\hline Power Distance & $\begin{array}{l}\text { - Orang yang berada di posisi yang lebih tinggi hendaknya membuat sebanyak mungkin } \\
\text { keputusan tanpa berkonsultasi dengan orang-orang di posisi yang lebih rendah (People } \\
\text { in higher positions should make most decisions without consulting people in lower } \\
\text { positions). } \\
\text { - Orang di posisi yang lebih tinggi tidak semestinya terlalu sering menanyakan pendapat } \\
\text { orang di posisi yang lebih rendah (People in higher positions should not ask the opinions } \\
\text { of people in lower positions too frequently). } \\
\text { - Orang di posisi yang lebih tinggi hendaknya menghindari interaksi sosial dengan orang } \\
\text { di posisi yang lebih rendah (People in higher positions should avoid social interaction } \\
\text { with people in lower positions). }\end{array}$ \\
\hline $\begin{array}{l}\text { Uncertainty } \\
\text { Avoidance }\end{array}$ & $\begin{array}{l}\text { - Merupakan hal yang penting bagi saya untuk memiliki petunjuk yang dijabarkan secara } \\
\text { rinci sehingga saya selalu mengetahui apa yang harus saya lakukan (It is important to } \\
\text { have instructions spelled out in detail so that I always know what I'm expected to do). }{ }^{\mathrm{b}} \\
\text { - Merupakan hal yang penting bagi saya untuk mengikuti instruksi/petunjuk dan prosedur } \\
\text { yang ada setepat mungkin (It is important to closely follow instructions and procedures). } \\
\text { Prosedur-prosedur kerja yang terstandarisasi atau baku sangatlah membantu bagi saya } \\
\text { (Standardized work procedures are helpful). }\end{array}$ \\
\hline Collectivism & $\begin{array}{l}\text { - Seseorang hendaknya mengorbankan kepentingan pribadi demi kelompoknya } \\
\text { (Individuals should sacrifice self-interest for the group). } \\
\text { - Seseorang hendaknya setia kepada kelompoknya meskipun dalam } \\
\text { pengalaman-pengalaman yang sulit (Individuals should stick with the group even } \\
\text { through difficulties). } \\
\text { Kesejahteraan kelompok lebih penting daripada ganjaran/penghargaan individual } \\
\text { (Group welfare is more important than individual rewards). } \\
\text { - Seseorang hendaknya hanya mengejar tujuannya setelah mempertimbangkan } \\
\text { kesejahteraan kelompok (Individuals should only pursue their goals after considering the } \\
\text { welfare of the group). } \\
\text { Kesetiaan terhadap kelompok hendaknya didukung atau digiatkan meskipun tujuan } \\
\text { perorangan mengalami sengsara (Group loyalty should be encouraged even if individual } \\
\text { goals suffer). }\end{array}$ \\
\hline
\end{tabular}

